University of Nebraska - Lincoln

DigitalCommons@University of Nebraska - Lincoln

\title{
Report of a Novel Biological Association for Paracrias huberi Gumovsky (Hymenoptera: Eulophidae) with Redescription of the Female and Description of the Unknown Male
}

\author{
M. A. Metz \\ Systematic Entomology Laboratory, USDA, ARS, PSI, c/o National Museum of Natural History, Washington, \\ D. C. 20013-7012, USA, markmetz@sel.barc.usda.gov \\ M. W. Gates \\ Systematic Entomology Laboratory, USDA, ARS, PSI, c/o National Museum of Natural History, Washington, \\ D. C. 20013-7012, USA, mgates@sel.barc.usda.gov \\ M. E. Schauff \\ Systematic Entomology Laboratory, USDA, ARS, PSI, c/o National Museum of Natural History, Washington, \\ D. C. 20013-7012, USA, mschauff@sel.barc.usda.gov
}

Follow this and additional works at: https://digitalcommons.unl.edu/systentomologyusda

Part of the Entomology Commons

Metz, M. A.; Gates, M. W.; and Schauff, M. E., "Report of a Novel Biological Association for Paracrias huberi Gumovsky (Hymenoptera: Eulophidae) with Redescription of the Female and Description of the Unknown Male" (2005). USDA Systematic Entomology Laboratory. 27.

https://digitalcommons.unl.edu/systentomologyusda/27

This Article is brought to you for free and open access by the Entomology Collections, Miscellaneous at DigitalCommons@University of Nebraska - Lincoln. It has been accepted for inclusion in USDA Systematic Entomology Laboratory by an authorized administrator of DigitalCommons@University of Nebraska - Lincoln. 


\title{
Report of a novel biological association for Paracrias huberi Gumovsky (Hymenoptera: Eulophidae) with redescription of the female and description of the unknown male
}

\author{
M. A. METZ 1 , M. W. GATES ${ }^{2}$ \& M. E. SCHAUFF ${ }^{3}$ \\ Systematic Entomology Laboratory, USDA, ARS, PSI, clo National Museum of Natural History, Washington, \\ D. C. 20013-7012, USA \\ email: ${ }^{1}$ markmetz@sel.barc.usda.gov, ${ }^{2}$ mgates@sel.barc.usda.gov, ${ }^{3}$ mschauff@sel.barc.usda.gov
}

\begin{abstract}
The female of Paracrias huberi Gumovsky (Hymenoptera: Eulophidae) is redescribed and the previously unknown male described from material collected by George B. Vogt near Plummers Island, Maryland. The species is diagnosed and placed within the current phylogenetic concept for the genus Paracrias. Collection records indicate this species was reared from Homoeolabus analis Illiger (Coleoptera: Attelabidae), which is a leaf-rolling herbivore of Quercus spp. and Castanea spp. (Fagales: Fagaceae), thus expanding the potential host guild range of the genus Paracrias and the known biology of the species. In addition, these records report an association with $Q$. prinus L., a species native to the eastern United States. The implications of these discoveries in relation to the biology of the plant, host, and wasp parasite are reviewed and discussed.
\end{abstract}

Key words: Chalcidoidea, Entedoninae, systematics, host, parasitoid, gregarious, Quercus montana, chestnut oak, George B. Vogt

\section{Introduction}

This is the first in a series of several papers in which we describe new chalcidoid taxa from the Nearctic and Neotropical regions collected by George B. Vogt. Vogt was an avid student of the biology of leaf-mining Coleoptera and leaf-rolling attelabids (Anderson et al. 1991). He traveled extensively from 1960 until his death in 1990 in the area between the eastern United States and Panama, and Brazil, amassing a collection of thousands of rearing records from a variety of host plants. Vogt was described as being eccentric in his record keeping (Anderson et al. 1991) and he left behind a trail of cryptic notes, but orga- 
nizational failings aside, his insect collection and associated writings represent a heretofore untapped wealth of biological information.

The genus Paracrias Ashmead is represented by 59 New World species showing their greatest diversity in the Neotropics. Hansson (2002) described 52 new taxa from material collected mostly in Costa Rica, but there are only three described species known from the United States; P. mirus (Girault), P. huberi Gumovsky, and P. arizonensis (Ashmead). We document the biological associations gleaned from the notes of Vogt for specimens of Paracrias huberi Gumovsky collected in Maryland as well as redescribe the female and describe the previously unknown male.

This species possesses the characters that define the current phylogenetic concept of the genus Paracrias as defined by Schauff (1985) and subsequently modified by Woolley \& Schauff (1987), Gumovsky (2001), and Hansson (2002) (antennal scrobes as distinct narrow grooves, posterior ocelli touching or nearly touching occipital margin, mandibles with 2 apical denticles, pronotal collar not carinate, scutellar-axillar suture without pit, propodeum with raised median area bordered by lateral sculpture and posterior edge projecting over foramen medially, scutellum without median groove, mid- and hindcoxal insertions well separated, stigmal vein sessile). Male and female specimens can be identified as Paracrias in the keys of Schauff (1991), Schauff et al. (1997), and Burks (2003).

\section{Methods}

Specimens were presumably placed in alcohol of an unknown concentration shortly after emergence in 1964 and left relatively untended until the present, whereupon they were discovered dry in vials and point or card mounted. Specimens were labeled with an identification number (Vogt coll. \#) when Vogt placed them into vials. Vogt collection numbers were formulated as a two-digit year followed by a number indicating the site (i.e., 63-1055 for site 1055 in 1963). Locality information was extrapolated from Vogt's field notes with the same Vogt collection number that read "nr P.I." adjacent to sequentially chronological collecting events at localities identified as "Nanjemoy" (Nanjemoy, Maryland). Country, State, and County names were added assuming a locality near Plummers Island, Maryland, a common collecting locality for Washington, D.C. scientists. Dates of collection and emergence for these specimens were recorded directly in Vogt's field notes. Specimens are deposited with the National Museum of Natural History, Smithsonian Institution, Washington, D.C., USA (USNM); the Canadian National Collection of Insects, Arachnids, and Nematodes, Ottawa, Ontario, Canada (CNCI); and The Natural History Museum, London, UK (BMNH).

Terminology for surface sculpturing follows Harris (1979) and for morphology follows Hansson (2002) and Gumovsky (2001). Body lengths are measured in lateral view from the anterior projection of the face to the tip of the gaster. Head width was measured through an imaginary line from gena to gena bisecting both toruli. Head height was mea- 
sured through an imaginary line from the vertex to the clypeal margin bisecting the median ocellus and the distance between the toruli. Antennae of both sexes were dissected and macerated in $\mathrm{KOH}$ to determine segmentation. Digital images were color corrected and backgrounds removed and otherwise edited as noted in the captions. All specimens were labeled with a USNM matrix code number to facilitate data entry and specimen identification. Specimen numbers are indicated in parentheses after specimens in the format "USNM ENTO 99999999."

\section{Paracrias huberi Gumovsky}

Paracrias huberi Gumovsky, 2001: 15. Holotype 우 (examined) and 2 paratype 우우 (CNCI).

Diagnosis and identification. Paracrias huberi belongs to the ordinatus group of species (Hansson 2002) by having an extremely reduced (absent) postmarginal vein, no setation at the base of the forewing (speculum), and sparse setation on the rest of the wing membrane. It runs through the key of Hansson (2002) to P. acidotus Hansson in couplet 61 and shares with $P$. acidotus the absence of a narrow strip of hyaline membrane along the anterior margin of the forewing. Paracrias huberi differs from P. acidotus by having three funicular segments and two claval segments in the female antenna (Fig. 2) (two funicular and three claval in P. acidotus); the medioposterior margin of the dorsellum blunt (not drawn out to a point) (Figs. 5 and 7); a much longer 9 gaster attributed to an extremely long ovipositor (Figs. 8 and 9); a smaller proportion (0.3) of the + gaster covered by first gastral tergite; and considerable differences in the shape and pattern of the propodeum including a longer nucha, a longer and narrower median carina, and narrower flattened areas laterad of the median carina that are acuminate posteromedially (Figs. 5 and 7).

The specimens from Maryland differ in several characteristics from those listed in the description of Gumovsky (2001) namely in having the female face golden and purple metallic (green in the description), the female face with broad areas of cuticle lacking areolation making it glabrous near the sulci (homogeneously reticulated in the description), the occipital margin carinate (rounded in the description), the ratio of the distance between the posterior ocelli and the distance from the posterior ocellus and the eye margin 4 (this ratio is 3.2 in the description), the female antenna inserted above the level of the lower eye margin (inserted slightly below lower eye margin in the description), and the legs shiny, dark brown (metallic in the description), but do not differ markedly from the examined holotype specimen, warranting a redescription of the species. Paracrias huberi was originally described from three females collected on Grand Manan Island off the extreme northern coast of Maine associated with Alnus sp., whereas the specimens from Maryland are associated with Quercus prinus, which has the extent of its northern distribution in extreme southwestern Maine. 
ZOOTAXA

1008
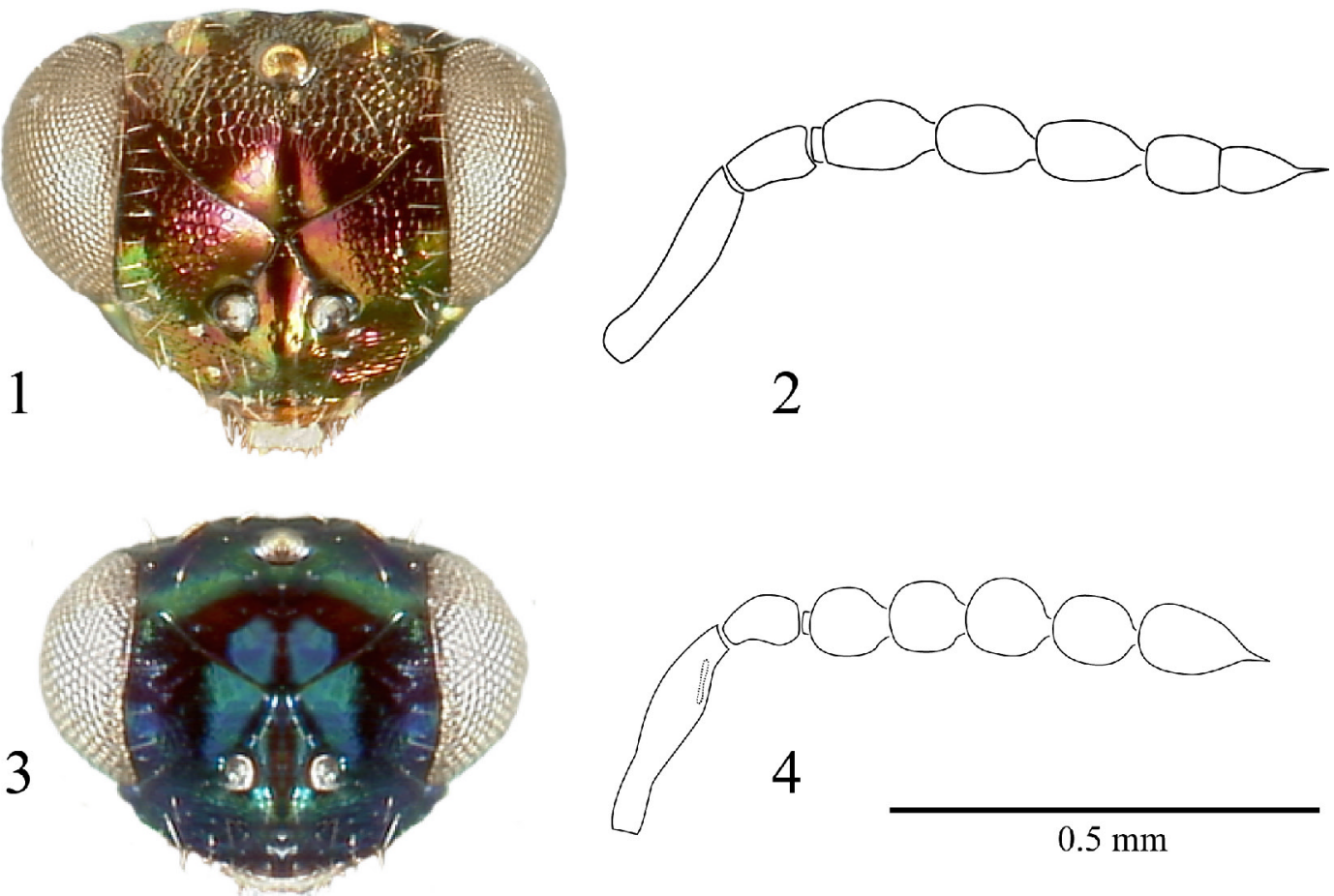

FIGURES 1-4 Paracrias huberi 1. ㅇ head, frontal. 2. ㅇ antenna, lateral. 3. $0^{x}$ head, frontal. 4. $\sigma^{x}$ antenna, medial.
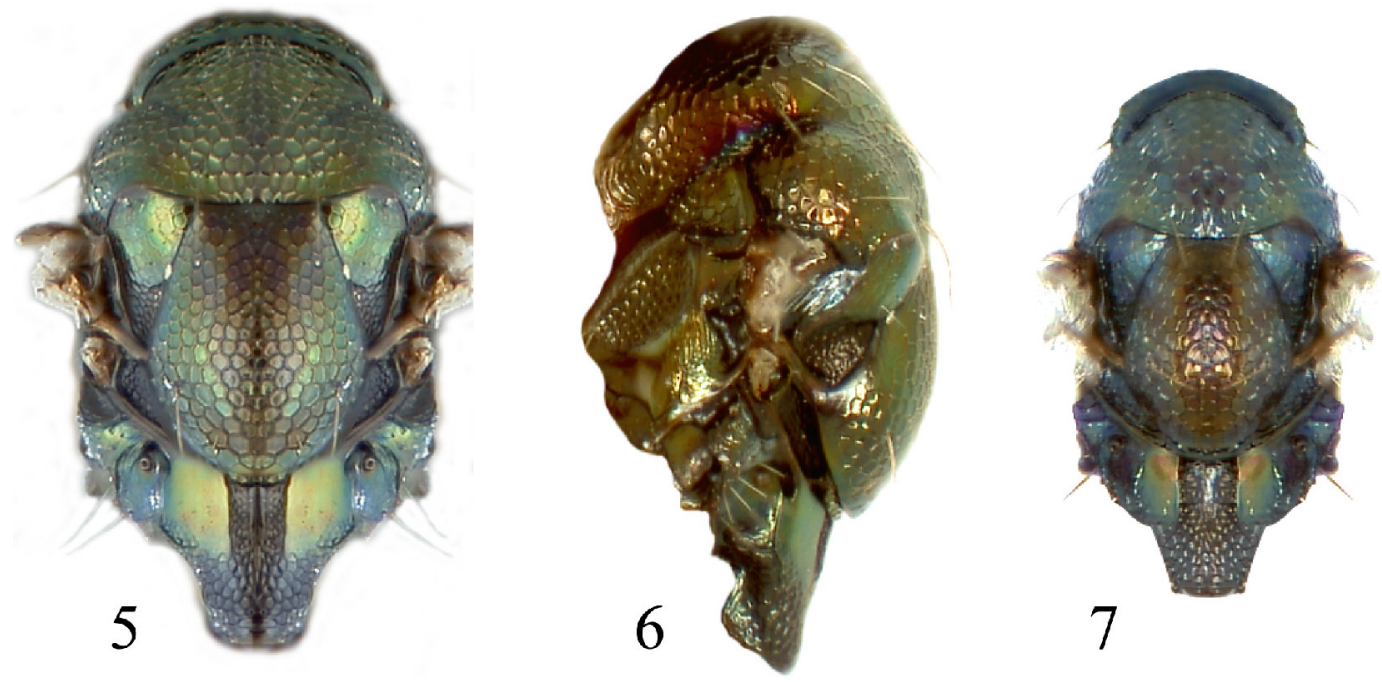

\section{$1.0 \mathrm{~mm}$}

FIGURES 5-7 Paracrias huberi 5. 우 mesosoma, dorsal. 6. ㅇ mesosoma, lateral. 7. $0^{\pi}$ mesosoma, dorsal. 

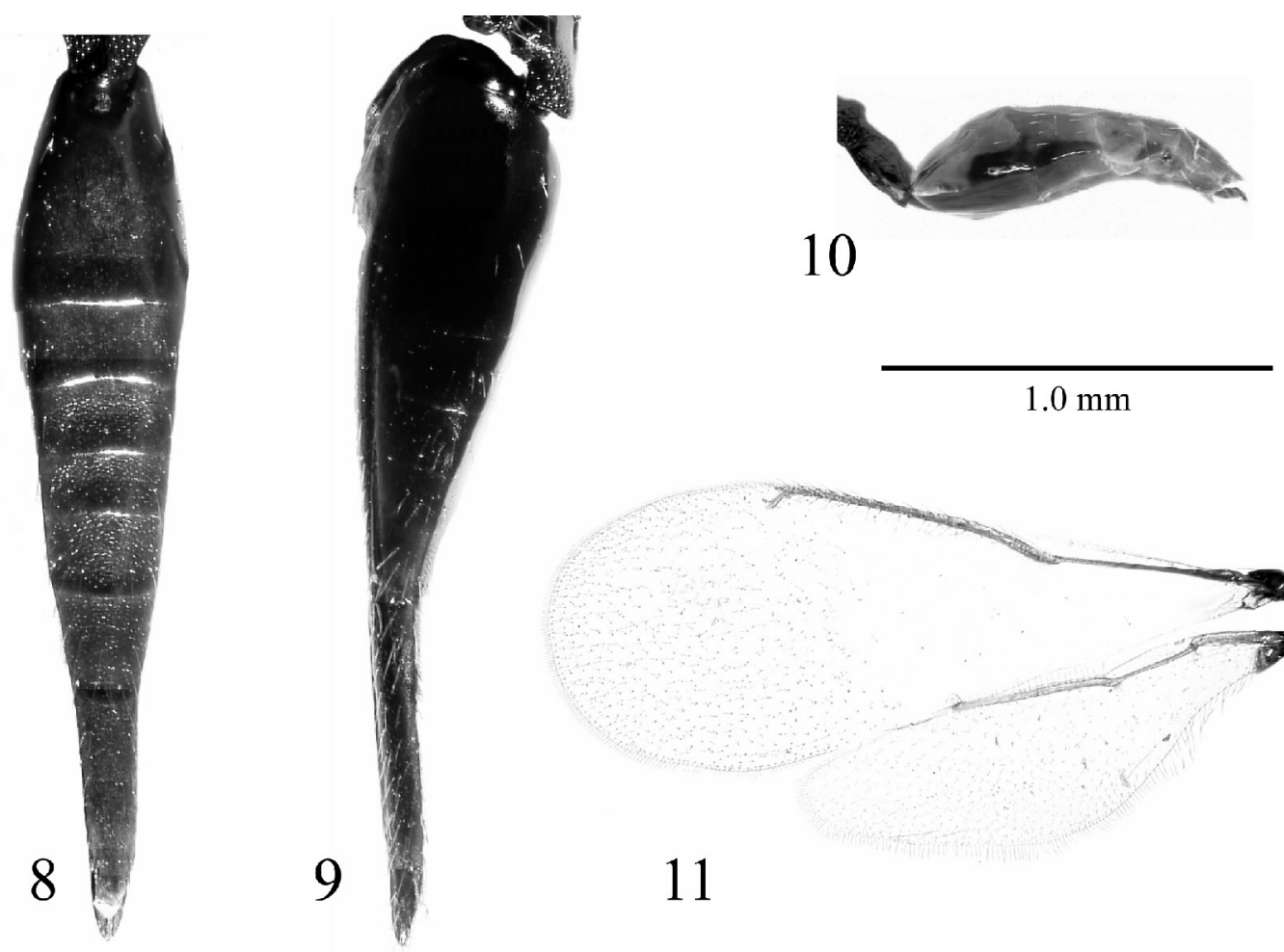

FIGURES 8-11 Paracrias huberi 8. ㅇ metasoma, dorsal. 9. ㅇ metasoma, lateral. 10. $0^{x}$ metasoma, lateral. 11. ㅇ left fore- and hindwing, dorsal.

Redescription of the female (Figs. 1, 2, 5, 6, 8, 9, 11). Length 3.0-3.7 mm. Mesosoma dark brown, with dark green and gold metallic reflections (Figs. 5 and 6); gaster dark brown, glabrous (Figs. 8 and 9). Antenna brown. Legs brown, except extreme apices of femora and tibiae pale yellow to white and tarsomeres 1-3 pale yellow to white. Forewing hyaline, veins brown to dark yellow, setae on disk short and sparse (Fig. 11).

Head (Fig. 1). Areolate to glabrous; occiput areolate; slightly broader than pronotum, subequal in width to widest point of mesosoma; height and width subequal; margin posterior to vertex carinate; with sparse setation on frons and face along eye margin, between and below toruli, and on outer margin of occiput; face and frons bright golden metallic with purple highlights. Antennal scrobes converging dorsally, meeting frontal suture independently; interscrobal area depressed, but face slightly elevated between and ventrad of toruli. Frontal suture "V" shaped, separated from inner eye margin laterally by less than one width of torulus. Posterior ocelli on margin of vertex, median ocellus separated from margin of vertex by one ocellar diameter. Distance between posterior ocelli 4.0X greater than between lateral ocellus and eye margin. Ventral margin of toruli level with ventral margin of eyes, toruli separated by 1 torulus diameter. Clypeal margin straight. Width of oral fossa $0.4 \mathrm{X}$ width of head. Antenna (Fig. 2). Scape $5 \mathrm{X}$ longer than broad, pedicel 
spindle-shaped, broader apically than basally. Flagellum with one anellus, three funicles, and a two segmented clava with a terminal spine. Anellus cylindrical, sides parallel. Funicles ellipsoidal, widest at middle; F1 slightly longer, F2-F3 subequal in length.

Mesosoma (Figs. 5 and 6). Pronotum short, transverse, slightly narrower than mesoscutum, areolate to shallowly areolate, extreme posterior margin glabrous, with a row of macrosetae along apical margin. Mesoscutum 1.5X broader than long, areolate; notaulus terminating in shallow depression; posterior margin of depression narrowly glabrous; with two pairs of dorsocentral setae. Axilla not projecting far forward of anterior margin of scutellum, glabrous at extreme anteromedial corner otherwise areolate. Scutellum $2 \mathrm{X}$ longer than broad; broadly convex dorsally. Dorsellum extremely short, not drawn out to a point; faintly reticulate. Propodeum (Fig. 5) areolate to areolate-rugose. Median carina elevated and flattened, glabrous; 4X longer than broad. Lateral flattened areas broad, subquadrate, glabrous, acuminate posteromedially. Propodeal callus with 5-6 setae. Prepectus and mesopleuron shallowly areolate with nearly isodiametric meshes, femoral depression glabrous ventrally. Coxae shallowly areolate to glabrous at margins; forecoxa with a row of filiform setae anterolaterally, mid- and hindcoxa with two to three filiform setae anteriorly. Hindtibia with apical seta short, half length of hind basal tarsomere. Forewing (Fig. 11). Setation sparse. Postmarginal vein $0.5 \mathrm{X}$ length of stigma. Speculum large, covering area $0.8 \mathrm{X}$ length of marginal vein anteriorly. Cubital setal line not evident.

Metasoma (Figs. 8 and 9). Petiole short, length and width subequal. Gaster $3 \mathrm{X}$ longer than mesosoma, glabrous; first gastral tergite glabrous with macrosetae laterally, oval membranous area reduced to vertical slit, slightly wider dorsally, without anterior hairtuft; second to sixth gastral tergite with short setation on disk with macrosetae laterally; hypopygium short, $0.1 \mathrm{X}$ length of gaster. Ovipositor sheaths not exerted.

Male (Figs. 3, 4, 7, 10). Length 1.4-2.0 mm. Similar to female in coloration and structure except as follows: frons and face extensively glabrous, lacking areolate sculpturing and uniformly dark metallic green, lacking bright gold and purple (Fig. 3); scape 3.0X longer than broad with ventral plaque in apical third; flagellum (Fig. 4) with anellus indistinct, appressed against F1 with line of demarcation noticeable only from some angles or after maceration, four funicular segments, and a 1-segmented clava; petiole $2.1 \mathrm{X}$ longer than broad (Fig. 10); oval membranous area of first gastral tergite shorter and of uniform width, gaster lacking acuminate terminal segments (Fig. 10).

Specimens examined (8 우, $21 \sigma^{x} \sigma^{x}$ ): USA; Maryland; Montgomery Co.; nr. Plummers Island; emerged from host 6.VI.1964; G.B. Vogt; Vogt coll. \#63-1056; reared from Homoeolabus analis (Coleoptera: Attelabidae) ex. leaf rolls of Quercus prinus L. (chestnut oak) collected 20.VII.1963. 6 우우 (USNM ENTO 00480116, 00480129, 00480163, 00480205, 00480228, 00480230) (USNM); 1 우 (USNM ENTO 00480178) (CNCI), 1 우 (USNM ENTO 00480198) (BMNH). 19 o o $^{x}$ (USNM ENTO 00480117, 00480124, 00480151, 00480156, 00480158, 00480166, 00480177, 00480186, 00480191, 00480204, 00480207, 00480216, 00480217, 00480221, 00480226, 00480229, 00480234, 00480235, 
00480241) (USNM), $1 \sigma^{x}$ (USNM ENTO 00480148) (CNCI), $1 \sigma^{x}$ (USNM ENTO

00480154) (BMNH) same data except, emerged from host 16-20.V, Vogt coll. \#63-1055.

\section{Discussion and Biological Information}

These specimen records detail the advantage of having material reared from hosts and having notes that detail biological information. In addition to gleaning the biological associations with other taxa, a greater number of specimens available from a similar collecting event can impart a better understanding of the morphological variation of a species. Of the 59 described species, only 12 have been described with males that can be associated with females. Hansson (2002) was able to associate males and females for eight species collected from Malaise traps in Costa Rica. The other four species were described from reared material, which provides a greater confidence for a conspecific correlation.

This is the first record of a species of Paracrias from a host that is not a seed-feeding weevil and the association of $P$. huberi with a larval host that has a leaf-rolling biology is remarkable. Paracrias anthonomi Woolley \& Schauff was reared from the boll weevil (Anthonomus grandis Boheman) in bolls of cotton, P. mirus was collected from the ash seed weevil (Lignyodes bischoffi (Blatchley)) in seeds of ash, and P. guatemalensis Hansson was collected from the avocado weevil (Conotrachelus perseae Barber) from the seeds of avocados. All of these insect herbivores are pests, some with considerable economic and/or environmental importance, but there is no research currently available exploring the use of any species of Paracrias as potential biocontrol agents.

This novel host-parasitoid account may be indicative of a taxon-associated coevolutionary relationship between the genus Paracrias and curculionoid beetles. The genus Homoeolabus is currently classified in the family Attelabidae, but this group was once considered a subfamily of Curculionidae and the taxa in these two families are certainly part of a monophyletic assemblage. This apparent taxon targeting may be due to host location through microhabitat. Chalcidoid wasps have been reported to use both chemical and mechanical cues to discover host location (Meyhöfer et al. 1997; Casas et al. 1998; Meyhöfer \& Casas 1999; and references therein), but there are no published accounts of behavior for the genus Paracrias. Size and shape are certainly different between leaf rolls and developing fruit, but perhaps chemical cues resulting from host feeding are comparable in different plant structures.

It is unclear from previous records whether reared series of other species of Paracrias emerged from a single host individual, although label data from $P$. guatemalensis and $P$. mirus suggest that they may be gregarious parasitoids. It is directly recorded for these specimens of $P$. huberi, however, that it is a gregarious parasitoid of Homoeolabus analis as Vogt indicated that multiple parasitoid specimens emerged from an individual host.

Chestnut oak ( $Q$. prinus L.) is native to the Appalachian range and adjacent hill country and its distribution extends west to Michigan and through northern Mississippi (USDA, 

and Illinois (USDA, NRCS 2004 as Q. montana Willdenow), these are local designations only; $Q$. prinus is not considered threatened or endangered on a continental level. In fact, several published reports suggest that $Q$. prinus has supplanted $Q$. alba L. or was originally the dominant canopy species in deciduous forest ecosystems from Ohio to the midAtlantic (Abrams \& McCay 1996; Norland \& Hix 1996; Abrams et al. 1997; LeBlanc 1998; Elliot et al. 1999; Abrams 2003). The discovery of the host-parasitoid relationship between $P$. huberi and $H$. analis may have implications for future biocontrol programs only in habitats where deforestation has affected the natural distribution of $Q$. prinus.

\section{Acknowledgements}

We thank the Smithsonian Institution Women's Committee (Grant \#2003-40), the Smithsonian Institution Entomology Division for supplies; Drs. Natalia J. Vandenberg, Thomas Henry, and Christer Hansson for their critical reviews and suggestions for this paper; and Mr. Jeffrey Chiu for assistance with data entry.

\section{Literature cited}

Abrams, M.D. (2003) Where has all the white oak gone? Bioscience, 53 (10), 927-939.

Abrams, M.D. \& McCay, D.M. (1996) Vegetation site relationships of witness trees (1780-1856) in the presettlement forests of eastern West Virginia. Canadian Journal of Forest Research (Journal Canadien de la Recherche Forestiere), 26 (2), 217-224.

Abrams, M.D., Orwig, D.A. \& Dockry, M.J. (1997) Dendroecology and successional status of two contrasting old-growth oak forests in the Blue Ridge Mountains, USA. Canadian Journal of Forest Research (Journal Canadien de la Recherche Forestiere), 27 (7), 994-1002.

Anderson, D., Bellamy, C., Howden, H., \& Quimby, C. (1991) George Britton Vogt (1920-1990). The Coleopterists Bulletin, 45 (1), 93-95.

Burks, R.A. (2003) Key to the Nearctic genera of Eulophidae, subfamilies Entedoninae, Euderinae, and Eulophinae (Hymenoptera Chalcidoidea). University of California, Riverside, California, 92521, USA. Available from: http//cache.ucr.edu/\%7Eheraty/Eulophidae/ (accessed 15 December 2004).

Casas, J., Bacher, S., Tautz, J., Meyhöfer, R. \& Pierre, D. (1998) Leaf vibrations and air movements in a leafminer-parasitoid system. Biological Control, 11, 147-153.

Elliot, K.J., Vose, J.M., Swank, W.T. \& Bolstad, P.V. (1999) Long term patterns in vegetation-site relationships in a southern Appalachian forest. Journal of the Torrey Botanical Society, 126 (4), 320-334.

Gumovsky, A.V. (2001) Review of the genus Paracrias (Hymenoptera, Eulophidae, Entedoninae). Vestnik zoologii, 35 (5), 9-26.

Hannson, C. (2002) Eulophidae of Costa Rica (Hymenoptera: Chalcidoidea), 1. Memoirs of the American Entomological Institute, 67, 1-290.

Harris, R. (1979) A glossary of surface sculpturing. Occasional papers in Entomology, no. 28. California State Department of Food and Agriculture, Sacramento, California, USA, $31 \mathrm{pp}$.

LeBlanc, D.C. (1998) Interactive effects of acidic deposition, drought, and insect attack on oak 
populations in the midwestern United States. Canadian Journal of Forest Research (Journal Canadien de la Recherche Forestiere), 28 (8), 1184-1197.

Meyhöfer, R., Casas, J. \& Dorn, S. (1997) Mechano- and chemoreceptors and their possible role in host location behavior for Sympiesis sericeicornis (Hymenoptera: Eulophidae). Annals of the Entomological Society of America, 90 (2), 208-219.

Meyhöfer, R. \& Casas, J. (1999) Vibratory stimuli in host location by parasitic wasps. Journal of Insect Physiology, 45, 967-971.

Norland, E.R. \& Hix, D.M. (1996) Composition and structure of a chronosequence of young, mixed-species forests in southeastern Ohio, USA. Vegetatio, 125 (1), 11-30.

Schauff, M.E. (1985) The New World genus Paracrias Ashmead (Hymenoptera: Eulophidae). Proceedings of the Entomological Society of Washington, 87 (1), 98-109.

Schauff, M.E. (1991) The Holarctic genera of Entodoninae (Hymenoptera: Eulophidae). Contributions of the American Entomological Institute, 26 (4), 1-109.

Schauff, M.E., LaSalle, J., \& Coote, L.D. (1997) Chapter 10. Eulophidae. In: Gibson, G.A.P., Huber, J.T. \& Woolley, J.B. (Ed) Annotated keys to the genera of Nearctic Chalcidoidea (Hymenoptera), NRC Research Press, Ottawa, Ontario, Canada, pp. 327-429.

USDA, NRCS (2004) The PLANTS Database, Version 3.5. National Plant Data Center, Baton Rouge, Louisiana, 70874-4490, USA. Available from: http://plants.usda.gov (accessed 15 December 2004).

Woolley, J.B. \& Schauff, M.E. (1987) A new species of Paracrias (Hymenoptera: Eulophidae) parasitic on Anthonomus spp. (Coleoptera: Curculionidae). Proceedings of the Entomological Society of Washingon, 89 (4), 770-775. 